\title{
History of Automobile Past and Present Challenges Facing Automobile Production in Nigeria
}

\author{
${ }^{1} \mathrm{Mr}$. Ohwojero Chamberlain, ${ }^{2}$ Prof. E.C. Ede. \\ ${ }^{I}$ Delta State University Secondary School P.M.B 1 Abraka, Delta State Nigeria,West Africa. \\ ${ }^{2}$ University of Nigeria Nsukka, Enugu Nigeria West Africa.
}

\begin{abstract}
The history of automobile in Nigeria started long before the country had her independence in 1960 between 1970 to 1980 . The Federal government in partnership with automobile company investors from the western world entered into agreement by spelling out mode of operation in terms of policy implementation and also assisting the country on technological advancement. The agreement made Federal government, to allow the establishment of six main Automobile plants, namely Peugeot Automobile Nigeria Limited (PAN), Volkswagen of Nigeria Limited (vwon), Anambra Motor Manufacturing Limited (ANAMMCO), steyr Nigeria Limited, National Truck Manufacturing (NTM) and leyland Nigeria Limited Ibadan (LNL).
\end{abstract}

Past and present history of Automobile was discussed, having in mind some of the challenges that has befall most Automobile industries in Nigeria. Based on the challenges discussed, findings were made for the purpose of finding solutions to the challenges that is facing automobile industries in the country. Based on the findings discussed, recommendations were made, that government should review policy establishing Automobile industries in the country, government should articulate all the problems facing Automobile industries in Nigeria etc.

Key words: Introduction, past history of Automobile $17^{\text {th }}-18^{\text {th }}$ century, present history of Automobile 18th -19 th century, challenges facing Automobile industries in Nigeria, production graph of (PAN), discussion of findings, recomedations, conclusion, references.

\section{Introduction}

The history of Automobile in Nigeria started earlier before Nigeria as a country had her independence in 1960. The western world introduced the use of automobile to Nigeria when oil was booming in the 70s. Developed countries like America, Germany, France, and Britain etc. through partnership with Nigerian government and issuing of license of operation and control policy, established six Automobile assembly plants in Nigeria, namely Peugeot Automobile Nigeria limited (PAN) Kaduna in 1975, Volkswagen of Nigeria Limited (VWON) Lagos 1978, Anambra Motor Manufacturing Limited (ANAMMCO) Emene - Enugu (1980); Steyr Nigeria Limited Bauchi, National Truck manufacturers (NTM) Kano Fiat Production, LeyLand Nigeria Limited (LNL) Ibadan, between 1970 and 1980 (Akiagwe 2010). The establishment of the six automobile assembly plant in Nigeria brought quick development to the country. According to Aganga (2013), the minister of trade and investment stated that "automobile industry is an engine of growth and stimulus to other economic activities like creating of employment opportunities growth of other satellite industries, enhancement of technology transfer of skill acquisition" since the establishment of the six automobile industries in the country, the economy of the country has improved tremendously because refined petroleum product are easily transferred from point of production to fuel filling stations. Farm produce are easily transferred from the northern part of the country to the South, West and eastern part of the country visa-vis. Human beings was able to travel with less stress from one location to another. Compared to when man was using animals as means of transportation.

Since in the year 2000, it has been recorded that there is a decline in the production of Automobile, some of the Automobile industries that were established between 70s and 80s are no longer in operation, as a result of challenges that has befall them. About 75\% existing Automobile companies in Nigeria today deal only on car sales, about $80 \%$ of Automobile used in the country today are fairly used cars popularly known as Tokumbo (Okuhu 2011), because of the decline in Automobile production in Nigeria. It is very pertinent that this study will look into some of the challenges facing Automobile industries in Nigeria. Also find possible solution on how some of these challenges can be solved to enhance production.

\section{Eras Of Automobile Invention (Past History $17^{\text {th }}-18^{\text {th }}$ Century)}

In the early 1672 Ferdinard Verbiest, a member of the Jesiut missionary in China built the first steam powered vehicle as a toy for the Chinese Emperor. Though it was of a small scale, it could not carry driver and passenger, but it was the first working steam powered vehicle. In the $18^{\text {th }}$ century a self powered steam propelled vehicle that is large enough to transport people and cargo was designed, by Nicholas - Joseph 
Cugnuot who demonstrated his fardier vapeurne (stream dray) and experiment stream driven artillery tractor in 1770 to 1771, but because Cugnuot could not prove the worth of his design. This made his work impracticable his invention was not developed in France where he hailed from. By 1784 center of invention was shifted to great Britain when William Murder built a working model steam carriage in Redruth, by 1801 Richard Trevithich that was running a full sized designed vehicle on the road in Camborne. This type of vehicle was in vogue for a time, such that innovation was done on it like inclusion of hand brake, multi-speed, transmission and better steering development. Some of this vehicle were used commercially for mass transit, until there was a back lash against large speed vehicle on road of united kingdom that resulted in the establishment of the locomotive act (1865) that required self propelled vehicles on public roads in the united kingdom to be preceded by a man on foot walking with a red flag and blowing a horn all these was because of saving life. (Verbiest 1679), (Echerman 2001) .

\section{III. $18^{\text {th }}-19^{\text {th }}$ century production era}

Before the $19^{\text {th }}$ century era, so many efforts were made before now like in 1815 a professor at Praque polytechnic, Josef Bocak, built an oil fired steam car. In 1838 walter Hancock built a steam bus, that has four seat steam phaeton. In 1867 a Canadian Jeweler Henry Seth Taylor demonstrated a four wheeled steam buggy at stand stead fair in strand steed, Quebec in London. In 1878 an American George B. Selden filed an application for a patent right before the American Government to have Authority over the produce of engine and other vehicle parts this was granted after 16years of the application. The American government granted the permission on November $6^{\text {th }} 1895$. Another popularly known inventor of numerous car-related technologist, Karl Benz received a German patent right in 1886, that was before George of American in 1895. Before now the four stroke petrol (gasoline) internal combination engine that constituted the most prevalent form of modern Automobile propulsion is a creation of Nikola-Otto in the $19^{\text {th }}$ Century. Similar four stroke diesel engine was invented by Rudolf Diesel, all these inventions gave rise to modern Automobiles. Adamson (1959). Buchanan (1958), Williams (2011).

\section{Verteran production era}

The first produced licensed Automobile was invented by Karl Benz in 1888 in Germany under license from Benz in France by Emile Roger. Though there were other tricycle builder Rudolf Egg, Edward Butler and Leon Bolle that used 650cc engine of his own design. By 18000, there was mass production of Automobile in France and United State. The first made car company in the world was produced by (Czech) company Nesseldorfer Wangenbau. The first company form exclusively to build Automobile was pan hard levassor in France, which also introduced the first four cylinders, engine that was formed in 1889. Two years later Peugeot as a man still in France started his own automobile company that was named after him Peugeot not until $21^{\text {st }}$ century when automobile industries was beginning to take off in the western Europe, especially in Franc where 30,204 vehicle were produced in 1903, representing 48, $8 \%$ of world automobile production that year. (Kearny and randy 2006), (Adamson 1859), (Vates 1988).

\section{Vintage Era}

The vintage era lasted from the end of the World War 11919 to 1929. During this period the front engine car came to dominate with close bodies and standardized contact that became a norm.

In 1919 over $90 \%$ of cars sold were open roof. By 1928 90\% were closed. The development of internal combustion engine continued at a rapid pace with multi-valve and overlapped camp half engine production at high end and, V8, V12, and V16 engine conceived for the ultra-rich. In 1919 also hydraulic brakes, were invented by Nalcolm longhead. Three years later, Hermann Rieselern of Vulcan Motors invented the first automatic transmission that had two speed planetary gear box, torque converter and lock up clutch that never entered production. During this era tempered glass, standard equipment inside windows was invented in France. In new York times, Taranto (1825), published that many manufactures were unable to keep pace with the bigger production units because of this, there was a fall in price of lower car that was commonly called COACH. Apart from the higher demand for smaller cars Taranto of U.s. also mentioned "Pyrocylin finish" the eight cylinder engine the four wheel brake and baloon tires as the biggest trend in 1825. (Myetymologycom 2012) (Georgano 1985).

\section{Modern Era (Present History)}

Before the modern era there was other era that was not mentioned in this study. Eras like pre world war II, Post war era, both eras gave the take off for the modern era in the recent time. The modern era is normally defined as the 25 years proceeding the current year. However, there are some technical and design aspects that differentiated modern era from past Automobile. Modern era Automobile has become one of the increasing 
standardization. Almost all the modern automobiles are computer aided. Some of the modern notable advance widespread Automobile was the front wheel drive and all wheel drive. The adoption of the diesel engine and the ubiquity of fuel injection, while all these advances were first attempted in earlier eras they so dominate the market today that it is easy to over look their significance. In the recent time nearly all the passenger cars are front wheel drive monologue, unibody design with transversely mounted engines.

Some of the exemplary modern cars are

1. 1966 - Present Toyota corolla -A simple Japanese saloon/sedan that has come to be the best - selling car of all times.

2. 1970 - Present Range rover -The first take on the combination of luxury and four - wheel drive utility.

3. 1973- present Mercedes Benz S - Class - electronic Anti - lock Braking system, Supplemental restrain airbag, seat belt pretensioners, and electron; c traction control system.

4. 1975-Present BMW 3 Series and 5 series. Been on car and driver magazines annual ten best list 17 times.

5. 1977- Present Honda Accord Saloon/sedan - a Japanese car that becomes most popular in the United States in the 1990s.

6. 1981-1989 Dodge Aries and Plymouth Reliant -the $\mathrm{h}$ - cars" that saved Chrysler as a major manufacturer.

7. 1983- Present Chrysler M; V; vans- the two bus minivan design that nearly pushed the station wagon out of market.

8. 1984- Present Renault Escape First mass volume commercial vehicle.

9. 1986- Present Ford Taurus- the mid sited front wheel drive sedan with modern computer- assisted design.

10. 1988 - 1989 Pontiac Transport - Was the first bus car

11. 997 -Present Toyota Prius - Launched in the Japan market.

12. 1998 -Present Ford Focus -One of the most popular hatch backs across the globe.

13. 2008- Present Tata name-The expensive car that was built by an - Indian company Tata motors.

14. 2010 - Present Nissan Leaf and Chevrolet Volt - an all electric car and a plug in lug braid correspondingly that was launched in the U.S and Japan market in December 2010. (Setright 2004), (Buchanan 1958), (Adamson (1959)

\section{Challenges Facing Automobile Industries in Nigeria}

The decline in production of automobile industries in Nigeria is becoming alarming, because in the past 20years production rate in the six established Automobile industries has fallen below expectation. Such that $80 \%$ of the established Automobile industries has folded up; the only existing Automobile industry out of the six that was established between 70s and 80s popularly known as (PAN) Peugeot Automobile Nigeria Limited that has a statistic production of 264 cars per day in the 80s has fallen to 22 cars per day as at 2011, (Abati 2009).

Some of the challenges that befall Automobile industries in Nigeria are discussed below:

\section{(a) Poor Policy Implementation:}

The establishment of Automobile industries in Nigeria is based on policy. The Federal government made a law in 1994, to protect and patronize the existing automobile industries in the country that was gazette, (No. 28 of 1994) which says "government at all levels and their agencies, must source all their vehicles from within the country, except where such Automobile are not available locally" (Akiegwe 2010). This law that was established by the federal government to assist and protect the local Automobile industries has been pushed aside; by the government itself. The government import foreign made Automobile rather than patronizing Nigerian made Automobile cars.

\section{(b) Poor Leadership}

In the past 20 years the government of Nigeria is not interested in the development of technological skills among her citizen. Every government believes that with the country natural resource which is the crude oil. The country stand not to face any economical crisis hence many past government leaders of this nation has mismanage the fund of the nation by siphoning money abroad building houses and companies abroad rather than investing money on local industries that will help to enhance production and create employment for her citizen.

A consultant in the Automobile sector Dr. Oscar Odiboh, stated that all developed economies of a nation solely depend on vibrant Auto-industry (Bisiriyu 2012).

\section{(c) High Tariff}

The interest rate placed on the purchase of a brand new car in the country today is on the high side, the cost of purchasing a new car in Nigeria is very high, such that an average Nigeria can not afford to buy a car of his choice. This boil down to cost of production that is facing Automobile industries, Nations like India, Russia 
try to reduce interest rate on loan for car purchase, to the tune of 5\% (percent) on car purchase, to encourage the local industries by indirectly reducing tax for part of the automobile industries.

\section{(d) Poor Economy}

The poor economy of the nation has hiking the price and maintenance of Automobile cars in Nigeria, owing a car in Nigeria is still a big thing. For most people to afford a car, it is a sign that poverty has been conquered. The arrival of a car in a family is often celebrated with a great happiness which characterizes the birth of a male child in the traditional African family. The cars being referred to in this context are not even brand new cars, but imported fairly used cars popularly known as "Tokunbo". Ukuhu (2011).

When a man buys a brand new car, he is said to have arrived. Parties are celebrated, neighbours are called and

Even the enemies are taunted prayerfully as having lost the battle. All these are caused by poor economy of the nation. But because the economy of the country is telling on the life style of her citizen, people no longer buy brand new cars and this tell on the success of automobile industries in the country.

\section{(e) Lack Of Fund}

The cost of running any industry in Nigeria is sole shouldered by the owners of the companies. The Nigeria government never think of a way out to support and encourage the existing companies, by ensuring or creating a conducive atmosphere for them to operate, but rather creating a way to share in the companies profit, by increasing the company tax yearly as a way of paying for their existence in the country. Odiboh the managing director of news letter Nigeria limited says that "A country that is developed has an automobile industry that is running; (Bisiriyu 2012), because the government of the country has failed to fund automobile industry in the country lack of fund is affecting most automobile industries.

\section{(f) Poor power Supply}

The power of any industry is electricity, lack of electricity in established industries result to stagnation of the company in terms of improvement and development. Most developed countries in the western world are able to survive based on the constant of electricity that is used in the operation of their machines. Automobile industry can only survive when there is a constant supply of electricity. The cost of purchasing fuel to run power plant during production and cost of maintenance is on the high side this affect the financial state of most automobile industry in Nigeria that is resulting to low production.

\section{VI . Statistic Annual Production of Peugeot Nigeria (Pan) From Year 2000 - 2013. The Only existing Automobile Industry for Now in Nigeria.}

Fig. 1

\begin{tabular}{|c|c|c|}
\hline YEARS & ANNUAL PRODUCTION & DAILY \\
\hline 2000 & 31200 & IOO \\
\hline 2001 & 28080 & 95 \\
\hline 2002 & 24960 & 90 \\
\hline 2003 & 24960 & 80 \\
\hline 2004 & 23400 & 75 \\
\hline 2005 & 21840 & 70 \\
\hline 2006 & 21840 & 70 \\
\hline 2007 & 18720 & 60 \\
\hline 2008 & 12480 & 40 \\
\hline 2009 & 12480 & 40 \\
\hline 2010 & 6864 & 22 \\
\hline 2011 & 0 & 0 \\
\hline 2012 & 0 & 0 \\
\hline 2013 & 0 & 0 \\
\hline
\end{tabular}




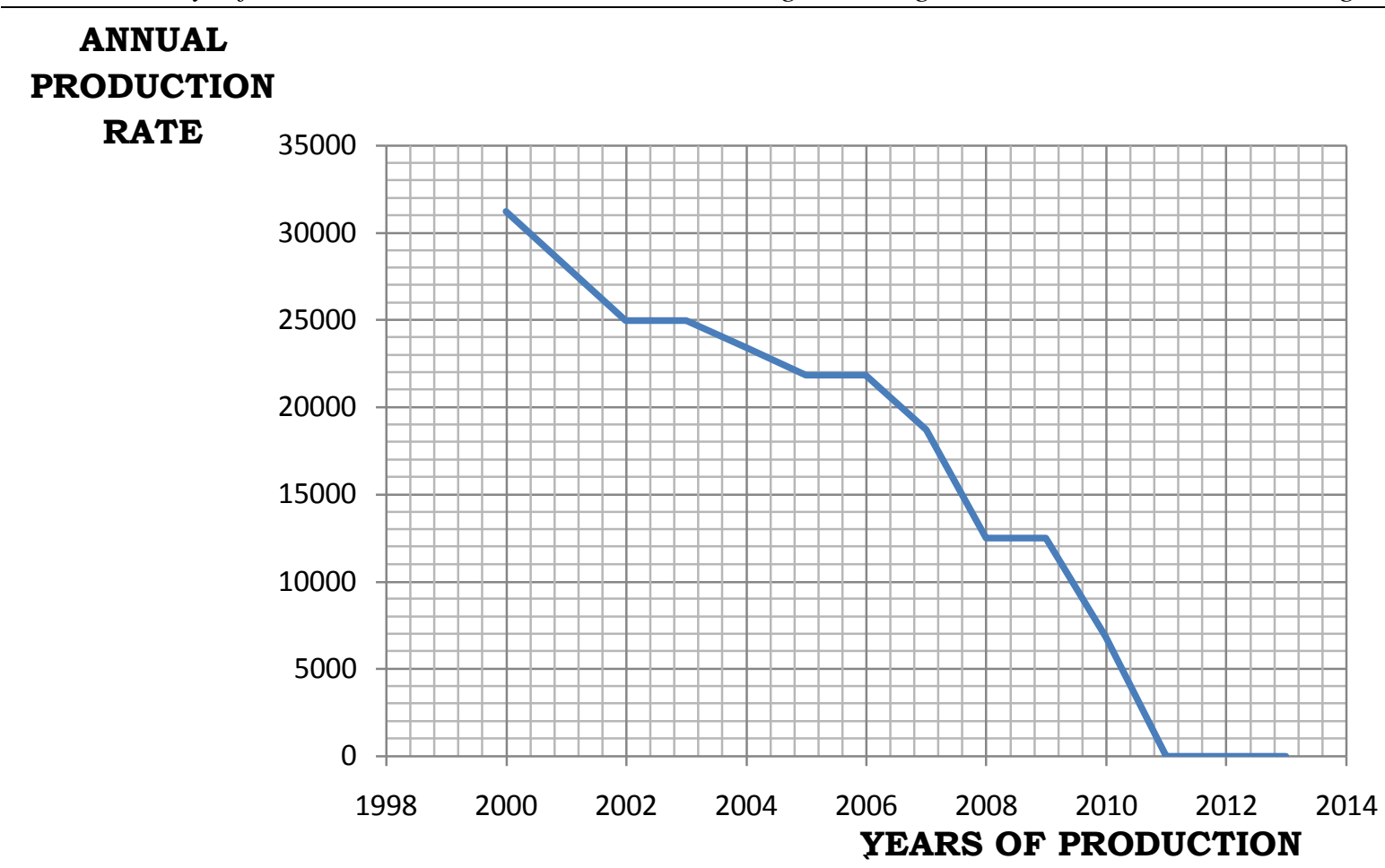

FIG II

\section{Discussing Of Findings}

The finding about the study is based on the data gathered from the statistical annual production shown on the graph in figure I1, from year 2000 to 2013.There is a decline in production rate from year 2000 to 2006 in the daily production. The decline in production is caused by some of the challenges that was enumerated in the study. Alhaji Bashir Borodo, the president of (MAN) manufacturer association of Nigeria, called on Nigeria government, all levels to patronize cars produced by (PAN) the only Automobile company still in existence in the country to survive (Abati 2009).

Production rate from the graph in figure I1, the decline in production fell down by $50 \%$ between year 2007 to 2010. Meaning that the challenges stated in the study, has an adverse effect on the management of the industry; this could cause poor economy in the nation's wealth, unemployment among the company staff and poor technological skill among the citizen of the country. The minister of trade and investment Olusegun Aganga stated in the $14^{\text {th }}$ annual Abuja motor show, that automotive industry is the engine of growth and stimulus to other economic activities (Bisiriyu 2012)

Production rate form the graph in figure I1, had zero \%( percent) production from year 2011 to 2013. Meaning at present production is no longer taking place in the company. From the graph it shows that the industry is at the verge of collapsing. This will have serious impact on the economic welfare of the nation, poor development, high standard of living, and other economic factors. This statement support Odiboh Oscar the managing director of newsletter Nigeria limited that says "developed economies have vibrant automobile industry (Bisiriyu, 2012)

\section{V11 Recommendation}

Recommendations were made based on the findings observed from the challenges, that affected the six established Automobile industries in Nigeria.

(1) Government should review the policy that govern the establishment of Automobile industries in Nigeria to give a good support in their existence. By imposing high tariff on the importation of vehicles, like Russia, India Malaysia government did to discourage the importation of foreign cars.

(2) Federal government should rise up and take the bull by the horn to face the challenges that is affecting the nation. A nation that put all her eggs in one basket stands the chance of losing all the eggs one day. Nigeria sees crude oil as the only means of survival of the nation. Most developed countries that do not have crude oil like Nigeria have buoyant economy because they take care of their Automobile industry rather than mismanaging their country fund. 
(3) The tax placed on the purchase of brand new cars in the country should be reduced, to encourage the buying of Nigerian made vehicles. Government should increase the tariff on the importation of foreign made vehicle to discourage importation of none Nigeria made car.

(4) Government should articulate all the problems facing Automotive plants. ANAMMCO, Volkswagen, Peugeot, Leyland, Steyr and Fiat, that stop existing for some years now and think of how to fund them with finance as a way of assisting Automobile industries in Nigeria.

(5) A country cannot develop without having a good power supply to run her industries. In the developed world like America Britain, Germany etc. are able to strive in their economy because of good power supply that is used to operate their industrial machine. A nation that is well industrialized has a good economy. So the Federal government should upgrade the power sector to enable local Automobile industries survive.

(6) The level of technological skill in Nigeria Automobile industries should be looked into by the Federal Government. This is because before now, the existing Automobile industries in Nigeria still use out dated technological method in carrying out production. Nigeria made vehicle still make use of carburettor system, contact breaking, manual steering.Technology has advanced more than this in the western world. Government in partnership with Automobile industries should be involved in exchange program, by sending workers abroad to acquire modern skills.

\section{Conclusion}

From the graph analysis showing the decline in Automobile production in Nigeria . It is clear that Automobile Industries in Nigeria are faced with so many challenges. These challenges identified can only be over come when government implement and support the stated recommendations. This is when Automobile industries in Nigeria can start production, to meet the demand of people, economic improvement and technological development of the country.

\section{Reference}

[1]. Abati. R. (2009), Pan and A Troubled Automotive Industry http://nigeriavillagesquare.com

[2]. Adamson J. F (1959), Engineering History of the Rambler and the Small Car Picture Today. Society of Automotive Engineers P.5

[3]. Aganga (2013); New Auto Policy is Ready. The punch Nigeria. http://www.punchng.com/business/industry

[4]. Akaigwe. M. (2010) Auto industry @ 50, so far so bad.

[5]. Bisiriyu R. (2012). New auto policy is ready http://www.punchng.com

[6]. Buchana C.D. (1958). Mixed Blessing: The Motor in Britain Leonard Hill. Eckermann E. (2001) World History of the Automobile, S.A.E press p. 14

[7]. Georgano G.N (1985) Cars: Early and Vintage, 1886-1930. London Grange-Universal ISBN 1-59084-49, 1-2.

[8]. Kearny M. Randy R (2006) Canada's first automobile full steam ahead ISBN 9781550026542.

[9]. Okuhit (2011), Sweet New Cars, Huge Maintenance Cost.

[10]. Setright L.J.K. (2004). Drive on: A social History of the Automobile origin to 1900 Herge.

[11]. Tatra Speed look encyclopedia (2012) Myetynology COM. Pp 12-14.

[12]. Vates B. (1988). "10 Best Mogulsi Car and Driver P. 47.

[13]. Verbiest R.P. (1679). Steam Chariot; History of the Automobile Origin to 1900 Herge.

[14]. William F (2011) A History of Wisconsin Highway Development 1835-1845. A joint project by the state, Highway commission of Wisconson and Public Roads Administration. 